\title{
短報
}

\section{治打撲一方が奏功した再発慢性硬膜下血腫の 1 例}

\author{
仲尾 貢二 $\mathrm{a}$ 金子 幸夫 ${ }^{\mathrm{b}}$ \\ a 塩川病院脳神経外科, 三重, $\mathbf{7} 514-0844$ 鈴鹿市平田1丁目3-7 \\ b 金子医院，三重，テ514-0035 津市西丸之内12-3サナダビル $2 \mathrm{~F}$
}

\section{A Case Report of Recurrent Chronic Subdural Hematoma Successfully Treated with Jidabokuippo}

\author{
Kouji NAKAO ${ }^{\mathrm{a}} \quad$ Yukio KANEKO $^{\mathrm{b}}$ \\ a Department of Neurosurgery, Shiokawa Hospital, 1-3-7 Hirata, Suzuka City, Mie 514-0844, Japan \\ b KANEKO Clinic, Sanada bldg. 2F, 12-3 Nishimarunouchi, Tsu City, Mie 514-0035, Japan
}

\begin{abstract}
We report a case of recurrent chronic subdural hematoma (CSDH) successfully treated with jidabokuippo. The patient was an 81 year-old woman who was performed burr hole surgery for left CSDH. Residual hematoma was gradually increased in postoperative serial brain CT. Although goreisan and saireito were administrated to prevent recurrence, the treatment was not effective. Thereafter, reoperation was performed because of the appearance of aphasia and right hemiparesis. Intraoperative findings revealed that the hematoma was viscous and was not enough drained. Since there was little improvement in clinical and CT findings, a phenomenon of the hematoma was considered as oketsu and jidabokuippo was administrated. Three weeks after the medication, right hemiparesis was improved. Seven weeks after the medication, the hematoma was markedly reduced. Taken together, these results strongly suggest that jidabokuippo is effective for postoperative recurrent CSDH which is difficult for drainage and has no response to the administration of goreisan and saireito.

Key words : chronic subdural hematoma, postoperative recurrence, oketsu, jidabokuippo

要旨

慢性硬膜下血腫（Chronic subdural hematoma：CSDH）術後再発症例に治打撲一方が奏功した症例を報告す る。症例は81歳女性，左CSDHに対して穿頭術を施行した。術後の経時的頭部 CTでは血腫は徐々に増大した。再 発防止に五苓散，柴苓湯を投与するも再発を防止することができなかった。失語症と右不全片麻痺を認めたため， 再手術を行った。術中所見では血腫は粘稠で十分にドレナージできなかった。臨床上および頭部 CT 上の改善に乏 しいため, 血腫を瘀血ととらえて治打撲一方を投与したところ, 投与後 3 週の時点で右片麻痺が改善, 投与後 7 週 の頭部 CT では明らかな血腫の減量を認めた。以上より，CSDHのなかでもドレナージが困難で利水剤に反応しな い再発症例に対し，治打撲一方は有用な治療薬になることが示唆された。

キーワード：慢性硬膜下血腫，術後再発，瘀血，治打撲一方
\end{abstract}

\section{緒言}

CSDH は，脳神経外科医が最も遭遇することの多 い手術疾患である。局所麻酔下の穿頭術による低侵 襲な外科治療が確立されており，一般的な予後は良 好であるが，術後の再発症例に難渋することも少な くない。

$\mathrm{CSDH}$ の保存療法については, 以前から利尿剂1) やステロイド2)の有効性が知られている。近年, 利 水剂に分類される五苓散の有用性が多数報告される ようになった。村松ら゙は11例の高齢 CSDH 症例に 五苓散を単独投与し，10例で血腫の消退，縮小を認
め，その有用性を報告した。この報告より以後は， 脳神経外科領域で五苓散への関心が高まり，五苓散 は現在では CSDH の薬物療法の主流を占めるよう になった。また，五苓散が無効な症例においては， 利水効果に加えて抗炎症作用, 内因性ステロイド分 泌促進作用を有するとされる柴苓湯の有用性が報告 され (4) $^{2} \mathrm{CSDH}$ の漢方治療には主にこの 2 種類の方 剤が使用されている。今回, 我々は, 五苓散, 柴苓 湯に反応しない $\mathrm{CSDH}$ 術後再発例に対し，治打撲 一方の投与によって有意な血腫の消退と臨床上の回 復を認め, 開頭術が回避できた症例を経験したので 
A.初回手術後47日目

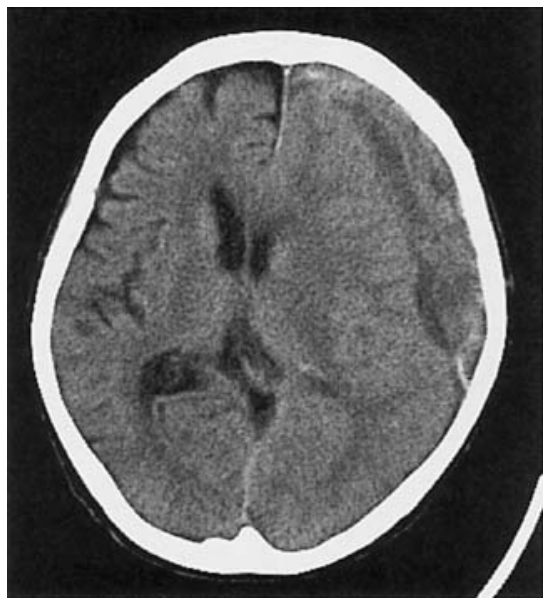

B.再手術翌日

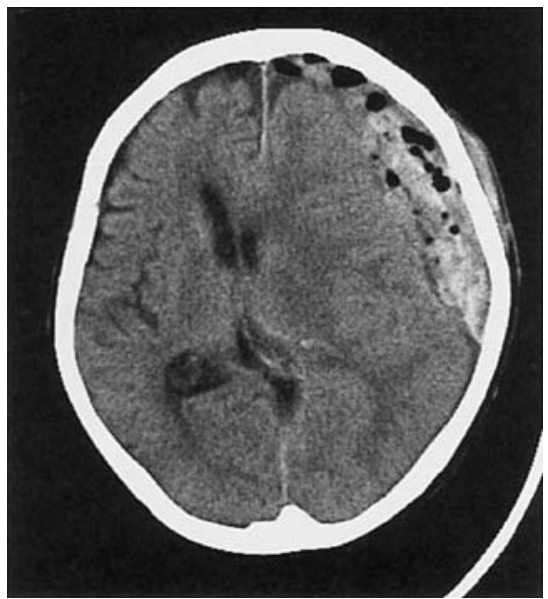

図 1 再手術術前, 術後の頭部 CT
A.投与開始前
B. 投与後 3 週間 独歩可能
C.投与後 5 週間 退院
D. 投与後 7 週間 独歩通院

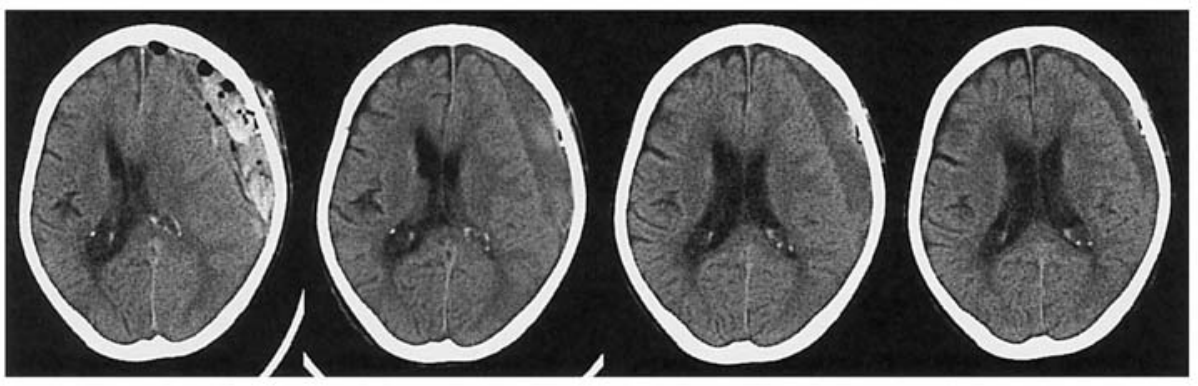

図 2 治打撲一方投与前後の経時的頭部 CT

報告する。

\section{症例}

患 者：81歳女性

主 訴：歩きにくい・元気がない

既往歴：特記すべきことなし

家族歴：特記すべきことなし

現病歴：患者は, アルツハイマー病で老人施設に 入所していた。ADLは日常生活には見守りが必要 だが自立していた。X年 9 月初旬, 左 CSDHに対 して穿頭血腫ドレナージ術を行った。再発防止に五 苓散, ついで柴苓湯を投与し, 外来にて経過観察を 行っていたが, 徐々に歩行障害と自発性低下が進行 した。初回手術後47日目の頭部 CT で明らかな血腫 の増量を認めたため, 再手術を目的に入院した。経 過中に明らかな頭部打撲は認めなかった。

入院時現症：身長 $150 \mathrm{~cm}$ ，体重 $34 \mathrm{~kg}$ で，やせ形。 顔貌は色白, 無欲状。脈弦。舌は, 歯圧痕はなく, 鏡面舌で, 舌下静脈の怒張を認めなかった。腹候は 軟弱で, 胸脇苦満, 少腹急結, 振水音はともに認め なかった。神経学的所見としては, 右利き, 右不全
片麻疩 $4 / 5$, 運動性優位の失語, 自発性低下, 歩 行障害が認められた。

経 過: 再手術術前の頭部 CT では, mixed density の左慢性硬膜下血腫を認め, これにより左半球 は圧迫され，右への正中偏位を認めた（図１Ａ）。 この血腫に対して, 初回手術後50日目に局所麻酔下 に再手術（穿頭血腫ドレナージ術）を施行した。術 中所見では, 血腫は半固形成分が多く粘稠で, 十分 なドレナージができなかった。術後 CT では, 残存 血腫が多く, 左半球への圧迫の解消は全く得られな かった (図1B)。臨床的には, 意欲低下と発語の そしい状態が持続した。この粘稠な残存血腫を水滞 ではなく症血ととらえ, 術後 5 日目から治打撲一方 $7.5 \mathrm{~g} /$ 日（分 3 ）の投与を開始した。投与後 3 週の 時点で右片麻痺は軽減し, 頭部 CT では投与前（図 2 A）と比較して血腫の減量を認めた（図 2 B)。 投与後 5 週で独歩可能となり元の施設に退院した。 頭部 CT では, 更に血腫は減量し, 正中偏位も軽減 した（図 $2 \mathrm{C}$ )。投与後 7 週の時点で, 外来には独 歩通院が可能で, 失語症はほぼ治癒していた。頭部 
CTでは, 血腫はさらに縮小し, 左半球への圧迫所 見の消退をみた（図 2D）ため, 治打撲一方の投与 を終了とした。

\section{考察}

治打撲一方は, 香川修庵の創製と浅田宗伯は述べ ている。その一方で, 戦国時代からその類方が使用 され，経験的使用によって伝承されて確立した処方 とみる向きもある。

『勿誤薬室方函口訣』によれば，「此ノ方八能ク 打撲, 筋骨疼痛习治ス。川骨, 血分ヲ和ス。樸樕骨 疼ヨ去ル。故二二味タモッテ主薬卜ス。」5) とある。 構成生薬は, 桂皮, 川芎, 川骨, 樸樕, 甘草, 大黄, 丁子からなる。本方は, 活血化瘀, 消腫, 通陽の処 方構成を有し，駆㾋血剂に分類され，骨折，打撲， 捻挫による腫脹疼痛に効果を表す。君薬の川骨, 樸 樕は代表的な駆㾐血剤である桂枝获苓丸, 桃核承気 湯, 通導散には含まれておらず, 治打撲一方に特徵 的な生薬である。香川修庵の『一本堂薬選』によよれ ば, 川骨（萍蓬根と記載されている）の効能は「破 痑血, 導新血, 打撲損傷, 徽毒㽽結, 産後疙血諸 疾」, 檏樕の効能は「破疼血, 徽瘡結毒, 諸悪瘡結 毒, 撲損宿滞疮血」と記されている。いずれの生薬 も，「破疹血」の記載から始まっているように，血 腫の治療に必要な処方構成と考えられる。使用目標 とすべき特別な脈証, 腹証はなく ${ }^{7)}$, 対症療法とし て使用されているのが実情である。本症例において も，漢方の診察では瘀血の所見にそしかった。

$\mathrm{CSDH}$ の術後の再発の頻度は, 文献的には1020\%と報告されている8 ${ }^{8}$ 。自験例では，2010-2014 の手術症例 58 例中 7 例に再発を認め, 再発率は $12 \%$ であった。その危険因子となる患者側の要因として は, 高齢, 脳萎縮, 抗血小板療法, 抗凝固療法, ア ルコール多飲, 血液透析などがあげられる。治療者 側の要因として大きなウエイトを占めるのが，不十 分なドレナージである。本例では，高齢・脳萎縮・ 不十分なドレナージが危険因子に該当し, きわめて 再発しやすく, 治療に難渋するCSDHに属し, 根 治するには開頭術をも考慮すべき状態であった。

近年, 慢性硬膜下血腫の保存療法に利水剂, 特に 五苓散と柴苓湯が非常に有効であることが多数報告 され ${ }^{3) \sim 5)}$, 広く脳神経外科領域で使用されるように なった。漢方医学的には, 血腫を水滞ととらえての 治療であることは論を俟たないが，その作用機序と
して五苓散が水チャンネルのアクアポリン (AQP) 4 を阻害することが解明されている9 。更に, 五苓 散と治打撲一方に共通する生薬の桂皮には, AQP 5 による炎症性サイトカイン克進を抑制する作用が報 告されており ${ }^{10)}$, 水の移動だけではない作用機序に よっても血腫の消螁に働いていることが示唆される。 本例も初回手術後早期から再発の兆しを認め, 再発 進行の予防に五苓散, 次いで柴苓湯を投与したが, 十分な効果を得ることができずに再手術に至った。 このことは「水」に着目した治療では限界のあるこ とが想定され，「血」を治療すべきであると考え， 駆瘀血剂の投与を行った。駆瘀血剤の中では, 治打 撲一方を第一選択として投与した。この理由として は, 筆者の経験上, 顔面頭部打撲後の腫脹, 皮下出 血に同方が非常に有効であったからである。また, 脳神経外科領域において, 高齢者の顔面打撲例 ${ }^{11}$, 開頭術後の頭皮腫脹例 ${ }^{122}$, 外傷後の帽状腱膜下血腫 例 ${ }^{13)}$ に対する有用性が報告されており，処方を選択 する根拠とした。これらの報告にあるような「頭蓋 外」血腫のみならず，本症例のような「頭蓋内」血 腫も同様に瘀血と考えて治打撲一方を投与したとこ ろきわめて有効であった。文献を渉猟する限り，治 打撲一方を CSDH に投与した報告は見当たらず， 本報告が最初であり重要と思われた。

\section{結語}

五苓散，柴苓湯などの利水剤に反応しない慢性硬 膜下血腫に対し，治打撲一方は有用な治療薬になり うることが示唆された。特に術後の再発例に対して は，非侵襲的治療の有力な選択肢として期待される。

付記 本論文の要旨は, 第68回日本東洋医学会学術 総会（2017年 6 月，名古屋）に扔いて発表した。

本症例に用いた治打撲一方は, ツムラ社製医療用工 キス顆粒である。

利益相反（COI）に関して開示すべきものなし。

\section{文献}

1 ) Suzuki J, Takaku A. Nonsurgical treatment of chronic subdural hematoma. J Neurosurg $1970 ; 33: 548-553$.

2 ) Glover D, Labadle EL. Physiopathogenesis of subdural hematomas. Part 2 : Inhibition of growth of experimental hematomas with dexamethasone. J Neurosurg 1976; 45 : 393-397. 
3 ）村松正俊, 吉川達也, 英賢一郎. 超高齢者の慢性硬膜 下血腫に対する五苓散料の効果. No Shinkei Geka $2005 ; 33: 965-969$.

4 ）北原正和. 慢性硬膜下血腫に対する柴苓湯の治療効果 に関する研究．脳神経外科と漢方 $2017 ; 3: 17-25$.

5 ) 浅田宗伯. 治打撲一方. 勿誤薬室方函口訣. 日本漢方 名医処方解説 折贵系 6 . オリエント出版社, 大阪 1989. 236.

6 ) 香川修庵. 一本堂薬選. 近世漢方医学書集成 69 , 名著 出版, 東京 1982. 29. 61 .

7 ) 高山宏世 編著. 治打撲一方. 腹証図解漢方常用処方 解説. 第56版, 三考塾叢刊. 日本漢方振興会, 東京 1988. 278-279.

8 ）宮上光祐, 賀川幸英. 慢性硬膜下血腫に対する五苓散 の有用性. No Shinkei Geka $2009 ; 37$ : 765-770.

9 ) Nakano T, Nishigami C, Irie K, et al. Goreisan prevents brain edema after cerebral ischemic stroke by inhibiting aquaporin 4 upregulation in mice. J Stroke Cerebrovasc Dis $2018 ; 27: 758-763$.

10) Sakamoto Y, Hisatsune A, Katsuki H, et al. Aquaporin 5 increases keratinocyte-derived chemokine expression and NF- $\kappa$ B activity through ERK activation. Biochem Biophys Res Commun 2014 ; 448 : 335-360.

11）吉田哲. 高齢者の顔面打撲に対する治打撲一方の効果. 脳神経外科と漢方 $2015 ; 1: 17-22$.

12）長嶋孝昭, 早川隆宣, 八ツ繁寛, 他. 重症頭部外傷に 対する減圧開頭術後の皮下腫脹に治打撲一方を行った 1 例. 脳神経外科と漢方 $2018 ; 4: 44-48$.

13）津金慎一郎, 福岡俊樹, 横山欣也, 他. 頭蓋骨骨折を 伴う帽状腱膜下血腫に対して治打撲一方が奏功した 1 例。神経外傷 $2011 ； 34 ： 192-195$. 